\title{
Türk Dil Devrimi ve Amerikan Dil Planlaması: Mukâyeseli Bir İnceleme
}

\section{Turkish Language Reform and American Language Planning: A Comperative Research}

\author{
Ahmet Naim Çiçekler ${ }^{1 \oplus}$, Tuncer Can $^{2 \oplus}$, Mehmet Yalçın Yılmaz ${ }^{3 \oplus}$
}

'Doç. Dr., İstanbul Üniversitesi, Edebiyat Fakültesi, Türk Dili ve Edebiyatı Bölümü, İstanbul, Türkiye ${ }^{2}$ Dr. Öğr. Üyesi, İstanbul Üniversitesi-Cerrahpaşa, Hasan Âli Yücel Eğitim Fakültesi, İngiliz Dili Eğitimi Anabilim Dalı, İstanbul, Türkiye ${ }^{3}$ Dr. Öğr. Üyesi, İstanbul Üniversitesi, Türkiyat Araştırmaları Enstitüsü, Türk Dili Bilim Dalı, Istanbul, Türkiye

\section{Sorumlu yazar/Corresponding author: Ahmet Naim Çiçekler, \\ İstanbul Üniversitesi, Edebiyat Fakültesi, Türk Dili ve Edebiyatı Bölümü, İstanbul Üniversitesi Edebiyat Fakültesi Türk Dili ve Edebiyatı Bölümü B Blok 3. Kat 1 numaralı oda, Fatih/Istanbul, Türkiye \\ E-mail: acicekler@gmail.com}

Geliş tarihi/Date of receipt: 15.10 .2018 Kabul tarihi/Date of acceptance: 09.11.2018

\section{Atıf/Citation:}

Çiçekler, A. N., Can, T. ve Yılmaz, M. Y. (2018). Türk dil devrimi ve Amerikan dil planlaması: Mukâyeseli bir inceleme. TUDED 58(2), 323-343. https://doi.org/10.26650/TUDED485808

\section{ÖZET}

Her toplumda iyi eğitim almış insanların telaffuz, cümle kurma ve ifade biçimleri örnek alınarak hazırlanan dilsel biçimler toplumda bütünleştirici bir rol oynamaktadır. Sosyo-politik ihtiyaçlara bir cevap olarak ortaya çıkan "Dil Planlaması", devletleşme ve uluslaşma süreçlerinin etkin ve önemli bir unsurudur. Tıpkı Türk Dil Devrimi'nde olduğu gibi dil planlaması ulus-devlet kurma sürecinde ortaya çıkmakta, belli bir ülkenin dilsel olarak homojenleştirilmesini hedeflemektedir. Dil politikası uygulamaları bir seferlik olabileceği gibi problemlere kısa süreli çözümler getirebilir veya uzun süreli amaçları benimseyebilir. İşte bu çalışmanın amacı da Amerika Birleşik Devletleri'nde uygulanan Dil Planlaması olgusunu Türk Dil Devrimi ile karşılaştırmaktır. ABD'de uygulanan dil planlaması Avrupa'dan gelen ve farklı dil konuşan göçmenlere, Amerikan Devleti'nin kolonileştirmek suretiyle kendi topraklarına kattığı ve farklı dil konuşan toplumlara, Yerli Amerikalılara ve ABD'ye köle olarak getirilen Afrikalı - Amerikalılara yönelik olarak farklıık göstermektedir. Bu bağlamda, bu çalışma her iki ülke tarafından dile yapılan müdahalelerin -bazı yönlerden benzerlik taşımakla birlikte- birbirlerinden önemli ölçülerde ayrıldıklarını ortaya koymaktadır. Örneğin, ABD'de Avrupalı göçmenlere yönelik politikalar daha çok "bütünleşmeye" (integration) yönelik yapısal asimilasyon olarak uygulanırken, Afrikalı - Amerikalılara yönelik dil politikası bir nevi "evcilleştirme"ye (domestication) yönelik davranışsal asimilasyon olarak uygulanmıştır. Türk Dil Devrimi ise doğrudan bütünleştirmeye odaklanmıştır.

Anahtar Kelimeler: Dil Politikası, Türk Dil Devrimi, Amerikan Dil Planlaması, Uyum Süreci, Dilbilim

\section{ABSTRACT}

The linguistic forms, which are distilled from the pronunciation, sentence formation, and expression of well-educated people, play an integrative role in society. Language planning, as a response to socio-political needs, is an effective and important element of the processes of state building and nationalization. Just as in the Turkish Language Revolution, language planning emerges in the process of a nation-state formation, aiming at linguistic homogenization of a particular country. Language policy practices can be one-off or short-term solutions to problems, or they can adopt long-term goals. In this respect, the aim of this study is to compare the phenomenon of language planning in the US with the Turkish Language Revolution. The language planning in the US, directed at European immigrants, differs from its applications towards people from colonies, for Native Americans, 
and for African-Americans. Thus, this study shows that the interventions made by both countries have similarities as well as differences, in some aspects, but they are quite distinct from each other. For instance, while policies towards European immigrants in the US are more commonly applied as structural assimilation regarding "integration," the language policy for African-Americans has been implemented as behavioral assimilation regarding "domestication." The Turkish Language Revolution is focused directly on integration.

Keywords: Language Planning, Turkish Language Reform, American Language Planning, Integration Process, Linguistics

\section{EXTENDED ABSTRACT}

Language Planning, which can be defined as the activity of consciously arranging the language or languages used by an official administration to solve problems related to the use of interlanguage differences, is a conscious intervention in the development process of a language. The linguistic forms, which are distilled from the pronunciation, sentence formation, and expression of well-educated people, play an integrative role in society. Language planning, also referred to as "language engineering," attempts to address the problems of a language rather than communication, and it expresses this change in the concrete form of the language in question. These changes are meaningful in practice because of the production of new words, the selection of a standard dialect, and the modernization of the language. This is a systematic intervention from the outside to the internal dynamic processes of language. This intervention can be arranged as "creative" or "limiting" by considering the status and prevalence of language. Creative interventions include functions such as writing a non-written language and producing new words. Restrictive interventions include the creation of standardization against geographical and social differentiation, or through language clearing from foreign influences. Language Planning, emerging as a response to socio-political needs, could be considered as an effective and important element in the processes of state building and nationalization. For example, in a process that started in the Seljuk period and continued in the Ottomans, the Turkish language was exposed to the intense influence by the Arabic and Persian languages. After the establishment of the Turkish Republic, however, the trend was reversed. In the context of the Turkish Language Revolution, language planning emerges in the process of nation-state formation, and it aims at the linguistic homogenization of a particular country. Language policy practices can be oneoff or short-term solutions to problems, or they can adopt long-term goals. For instance, after Turkish Language planning had started, Ataturk himself paid visits within the country to attend the struggle to teach the newly established alphabet. Since language planning is a type of planning that is frequently encountered in multilingual societies, it is a fact that it has been carried out in many other countries before the Turkish Language Revolution. The Germans, the Swedes, the Hungarians, the Finns, and the Albanians carried out a deliberate mobilization by placing the words that were the product of their native language, by liquidating the non-native foreign words in their language with the nationalist tendencies they conducted. Accademia della Crusca was founded in 1582 in 
Italy in order to free Italian from foreign words. In 1635 in France, the French Academy was founded in order to regulate the existing language and pronunciation, and to establish a refined oral and written communication language. In this respect, the aim of this study is to compare the phenomenon of Language Planning in the United States with the Turkish Language Revolution. The Turkish Language Revolution does not only include language simplification. It also includes the transition from the Arabic letters to a new alphabet, the Latin alphabet. On the other hand, language-planning applications in the United States directed at European immigrants who speak different languages differ from its applications for people from places colonized by the US, which include Native Americans and African-Americans brought to the US as slaves. In this context, this study shows that the interventions made by both countries have similarities as well as differences in some aspects, but they are quite distinct from each other. For example, the development of literacy has become one of the main goals in both types of language planning. However, while policies towards European immigrants in the United States are more commonly applied as a structural assimilation towards "integration," the language policy for AfricanAmericans has been implemented as a behavioral assimilation towards "domestication." The Turkish Language Revolution is focused directly on integration. 


\section{Dil Planlaması}

Dil Planlaması terimi Haugen tarafından 1959 yılında ilk olarak kullanıldıktan sonra, Joshua A. Fishman'ın 1966 yılında yayımlanan Language Loyalty in the United States isimli kitabı konu hakkındaki en kapsamlı eser olarak karşımıza çıkmaktadır. Bir toplumda dillerle veya dil-içi farklılıkların kullanımı ile ilgili problemlerin çözülmesi için kurumsal yapılar yoluyla yapılan açık ve sistematik müdahale (Yılmaz, 2013, s. 1) olarak tanımlanabilecek "Dil Planlaması" bir dilin gelişim sürecine bilinçli bir müdahale olarak görülmektedir. Kummer ve Gramley'e (2008, s. 291) göre de yerel, ulusal ya da ulusüstü politik organizasyonların dilin düzensiz gelişimine karşı olan müdahalesi veya bunun herhangi bir biçimi, dil planlaması ya da dil politikası olarak değerlendirilebilir. Dilde standartlaştırma her toplumda belli bir bölgenin/şehrin şivesi temel alınarak yapılır. Örneğin Türkçe, İstanbul şivesinde kendiliğinden standartlaşmıştır. Yönetimler de buna itiraz etmediğinden herhangi bir düzenlemeye gitmemiştir; bu yaklaşım toplumda bütünleştirici bir rol oynamaktadır. Bununla birlikte aynı dilin zamanla değişen farklı kullanımlarının oluşmasına engel olmak, dilin doğal işleyiş̧ine müdahale edilmesi anlamına gelmektedir. Dil üzerinde yapılan bu tarz müdahaleler ise modern dilbilim anlayışıla ters düşmektedir. Buna benzer bir müdahale olan "statü planlaması" kavramında da ortak siyasal sınırlar içerisinde yer alan ve birbirleriyle ilişkili dillerin yasal statülerini düzenleme göze çarpmaktadır. Bu müdahale pratikte devletin çok dilliliği tanıması ya da yok sayması olarak görülmektedir (İmer, 2001, s. 341).

Azınlıkların insanî ihtiyaç ve haklarına bir cevap olarak yabancı/ikinci dil öğretimine yönelik, ekonomik çıkarlar, güvenlik değerlendirmeleri ve jeopolitik kaygılar sonucunda ortaya çıkan Edinim Planlaması (Acquisition Planning); politik bir değişim sonucunda veya ölmekte olan bir dili tekrar canlandırmak için ortaya çıkan Kullanım Planlaması (Usage Planning); estetiğin ya da entelektüelitenin standart dil üzerine yaptığı etki anlamına gelen Prestij Planlaması, Lo Bianco'nun Söylem Planlaması üst başlığı altında verdiği dil planlaması biçimleridir. Türk Dil Devrimi, bu tasnif içerisinde Kullanım Planlaması başlığı altında kabul edilebilirken Amerikan Dil Planlaması da Edinim Planlaması ve Prestij Planlaması başlıkları altında değerlendirilebilir (Bianco, 2010, s. 147). Bir toplumdaki Sosyo-politik ihtiyaçlara bir cevap olarak ortaya çıkan devletleşme ve uluslaşma süreçlerinin etkin ve önemli bir unsuru olan "Dil Planlaması"nın ihtiyaç duyulduğu durumları ve dil planlaması üzerinde çalışan bilim dallarını Yılmaz şu şekilde belirtmektedir (Yılmaz, 2013, s. 1-2):

Dilsel grupların sayısının arttığı ve rekabet edemediği durumlarda, belirli bir dilsel azınlığın yok olmaya başladığı dönemlerde dil planlamasına ihtiyaç duyulabilir. Dil planlaması genellikle sosyo-politik sorunlara çözüm amaçlı yapıldığı için ilk etapta sosyologlar ve siyaset bilimciler tarafından çalışılmış; dilbilimciler ise dil planlaması esnasında dilin lehçe ve ağızlarının ihtiyaçlar doğrultusunda belirlenmesi aşamasında sürece dâhil olmuştur. Dilbilimciler sözdizimi veya morfolojinin standartlaştırılması, sözlük çalışmaları gibi 
konularda yol gösterici olabilir. Eğitimciler bu sürece belirlenen ihtiyaçları karşılamak için programlar geliştirerek katılabilir. Yazarlar da ölü dilde ya da fazla yazılı kaynağı bulunmayan dilde eserler üreterek bu süreci destekleyebilir. Ulusal dil akademileri de dil planlamalarını destekleyebilir.

Yılmaz'dan iktibas edilen yukarıdaki paragraftan da açıkça görüleceği üzere bir dil üzerinde uygulanan dil planlaması, tek bir kurum tarafından değil birden fazla alanların katılımı ile gerçekleştirilmektedir. Bir dile bilinçli bir müdahale olarak tanımlanan dil planlaması sürecinde şu aşamalar izlenmelidir (Yılmaz, 2013, s. 3):

a. Veri toplama aşaması: Bu aşamada planlama yapılacak dilin kullanım biçimleri, kullanıldığı bölgeler, diyalektleri gibi konularda araştırmalar yapılır. Bu dil ve koşullar için hangi planlama türünün daha uygun ve daha etkili olacağı belirlenir.

b. Planlama aşaması: Bu aşama planlama kararının alındığı aşamadır ve planlama yoluyla ulaşılması hedeflenen sonuçlar net bir biçimde ortaya konur. Aynı zamanda bu hedeflere ulaşmak için izlenecek yol belirlenir.

c. Uygulama aşaması: Bu aşamada uygulamaya geçilir ve planlama sürecinin işleyişinde bir aksaklık olup olmadığı konusunda sürekli denetimler yapılır.

d. Deneme aşaması: Bu aşama planlama sonucunda toplumun nasıl bir tepki verdiğini gösteren aşamadır ve bu aşamada planlayıcı mekanizma, uygulanan planın ne ölçüde istenilen yönde işlediğini takip etmektedir. Planlamaya başlamadan önce belirlenen muhtemel sonuçlar ile planlama sonunda ortaya çıkan sonuçları karşılaştırır. Planlama sonucunda karşılaşılan bir aksaklık varsa bunun sebepleri incelenir ve yeni planlama girişimleri için toplumdan alınan geri bildirimler değerlendirilir.

Türk Dil Devrimi'nde olduğu gibi dil planlaması ulus-devlet kurma sürecinde ortaya çıkmakta, belli bir ülkenin dilsel olarak homojenleştirilmesini hedeflemektedir. Çok dilli toplumlarda sıkça karşılaşılabilecek bir planlama türü olan dil planlaması uygulaması birçok ülkede gerçekleştirilmiş bir olgu olarak karşımıza çıkmaktadır. Alman, İsveç, Macar, Fin ve Arnavut toplumları tarafından yürütülen milliyetçi politikalar, kendi dillerindeki yerli olmayan yabancı sözcükleri tasfiye ederek yerlerine yerli, kendi dillerinin ürünü olan sözcükleri koymak şeklinde bilinçli bir seferberlik olarak tanımlanabilir. Accademia Della Crusca 1582 yılında İtalya'da kurulan ve kendi dillerini yabancı unsurlardan kurtarmayı hedefleyen bir akademidir (Yılmaz, 2013, s. 8-9). Benzer şekilde Fransa'da 1635 yılında Fransızcanın söz varlığını, dil bilgisini ve telaffuzunu düzenlemek, rafine bir sözlü ve yazılı iletişim dili oluşturmak için Fransız Akdemisi kurulmuştur. Fransa'da 17. yüzyılın sonunda Fransız Akademisinin yanında bölgesel akademiler de kurulmaya başlanmış ve bahsi geçen bu bölgesel akademiler 18. yüzyıl boyunca da varlıklarını sürdürmeye devam ederken Fransız İhtilali ile birlikte yapılan değişikliklerle bölgesel akademilerin çoğu ortadan kalkmış, geriye şu an da varlığını sürdüren Fransız Akademisi kalmıştır (Hakan, 
1982, s. 222-223). İtalyan ve Fransız dil akademilerinin yanında Lewis, başka ulusların gerçekleştirdikleri dil planlaması hareketlerini ise şu şekilde açıklamaktadır (Lewis, 2007, s. 2-3):

Almanca konuşulan topraklarda Fransızcanın yayılması 16. yüzyılın sonunda başladı. Bu duruma yapılan itirazların ilk kıvılcımları ise yüz yıl sonra görüldü, fakat bunların Prusya Kralı 1. Fiedrich Wilhelm üzerinde hiçbir etkisi olmadı. Bu durum onun asilzadelerine yönelik meşhur bildirisinden de anlaşılabilir. Modern Almancanın vokabülerindeki, uluslararası kelimeler olan Telefon ve Auto'nun yerini alan Fernsprecher ve Kraftwagen kelimeleri -gerçi bu ilk ikisi sonradan geri gelmişlerdir- buna benzer bir başka seferberliğin sonuçlarına işaret etmektedir. Macarcayı Almanca ve Latince kelimelerden temizleme maksatlı bir hareket de 18. yüzyılın ikinci yarısında başlamış ve hatırı sayılır bir başarıya ulaşmıştır. Fransız Akademisi uzun zamandır Franglais kelimelerin akınına rağmen yitirilmiş bir savaşta kavga vermeye devam etmektedir.

Ingilizceyi arındırma yönünde teşebbüsler de yapılagelmiştir. Sözün gelişi, Inwit 1230 yılları civarında yazılmış Ancrene Riwle'de conscience (vicdan) yerine kullanılıyordu. 1340'da Dan Mitchel Ayenbite of Inwit'i yazdığında, ayenbite (again bite: tekrar ısırış) kelimesini son dönem Latince Remorsus "remorse"un (pişmanlık) tercümesi olarak kullanmıştı.

Makalenin ilerleyen bölümlerinde daha detaylı olarak aktarılacağı üzere resmî dili İngilizce olan ABD, anadili İngilizce olmayan toplulukların çoğalması sonucu 1986 yılında ABD Anayasası ve California Düzenlemesi'nin 63. Önermesi (Başçetinçelik, 2018) ile İngilizce dışındaki dillerin resmî alanlarda kullanımını kısıtlarken sadece İngilizcenin resmî statüde bir dil olduğunu belirten bir düzenleme çıkarmıştır.

\section{Türkiye'de Dil Planlaması}

Ahmet Caferoğlu Türkçenin yabancı dillerden sözcük ödünçlemekten çekinmediğini şu sözlerle anlatmaktadır (Caferoğlu, 2000, s. 2):

İki bin yıl gibi uzun bir zaman aşamasında, vücuda getirilen ve tarihte diğer milletlere nasip olmayan, geniş varlıklı ve ömürlü Türk siyasî birlikleri, şüphe yok ki, devletçilik hayatlarında, birbirlerinden farklı medeniyetlerle temasa gelmiş ve bu yüzden, her dâim üstünleşmek ülküsünü güden Türk şiveleri de muhtelif yabancı dillerden, şivelerden kelime ödünç almaktan çekinmemişlerdir.

Hiçbir dil saf olmadığından, her dil muhtelif sebeplerle etkileşim içinde bulunduğu farklı dillerden yapılan sözcük ödünçlemeleri ile zenginleşmektedir. Dilin doğası gereği oldukça normal olan bu durum Türkçede ödünçlemeden ziyâde Türkçenin istilâsı hareketine dönüşmüştür. 18. yüzyılda yaşamış olan Mustafa el-Bağdadî isimli bir mütercim Fuzûli'nin 
Farsça olarak kaleme aldığı Sıhhat ü Maraz risalesini Türkçeye çevirme sebebini şu sözlerle açıklamaktadır (Çiçekler ve Kaçar, 2018, s. 42):

Ve ba'd: Mu'tekıf-i zâviye-i acz ü inkisâr, ya'nî Fuzûli-yi hâksâr ki muharrir-i selâsil-i hikâyet ve müessis-i bünyân-ı rivâyetdir, zebân-ı Fârisî ile rûhun hikâyetini ve hüsnle aşkın rivâyetini beyân eyledi; ve bu abd-i hakîr el-Hâcı Mustafâ el-Bağdâdî, sâkin-i mahrûse-i Haleb iken zebân-ı Fârisîden lisân-ı Türkîye tercüme eyledim ki Fârisîde piyâde olanlar terkîbini fehm ideler. Bugüne nakl olundı ki.

Fuzûli'nin eserinin çevirisinden alıntılanan paragrafta sadece dokuz adet Türkçe ifade bulunmakta ve bunlardan beş tanesi yardımc fiildir. Farsça olan bir eseri Türkçeye çevirirken bile Türkçe sözcük veya dilbilgisel yapıların kullanımı Arapça-Farsça muadillerine oranla oldukça az olarak göze çarpmaktadır.

\section{Cumhuriyet Öncesi Dil Tartışmaları}

Bu bölümde Türkçedeki dil tartışmalarına Türkiye Türkçesinin temeli olan Oğuz Türkçesinden başlanacaktır. Selçuklular döneminden başlayıp Osmanlılar döneminde de devam eden süreçte Türkçenin Arapça ve Farsçanın yoğun bir şekilde istilasına maruz kaldığı açıkça görülmektedir. Toplumdan dilsel anlamda kopuk bir yönetici ve egemen sınıfın ortaya çıktığı Selçuklular döneminde Türkçe sadece halk arasında kullanılan bir dil olarak karşımıza çıkmaktadır. Fuad Köprülü bu durumu şu şekilde açıklamaktadır (Köprülü, 1928, s.10-11):

Anadolu'da... klâsik Acem şi'irini model ittihaz eden 'saray şairleri'ni daha Selçukîler sarayında görmeye başlıyoruz... Iran tesiratının mütemadi kuvvetle nemasına ve Acem modellerinin taklidine daimî bir terakki gösterilmesine rağmen, Türkçe yazan şairler ve müellifler, eserlerinde hemen umumiyetle: "Türkçenin Arapça ve Acemceye nispetle daha dar, daha kaba, ifadeye daha kabiliyetsiz olduğunu, ve binaenaleyh kendi kusurlarına bakılmamak lâzım geldiğini" söylüyorlar, hatta bazen zımnî bir mazeret şeklinde 'Arabî ve Farsî bilmeyen halkın anlaması için Türkçe yazmaya mecbur olduklarını ilave ediyorlardı.

Türkçe, kendi dillerini kusurlu gören ve ancak cahil halkın anlaması için Türkçe yazan bir zümre bulunmasına rağmen hayatını devam ettirmiştir. Beylikler dönemiyle birlikte Selçukluların aksine Arapça ve Farsça karşısında Türkçenin üstün olduğunu kanıtlama mücadelesinin, özellikle Anadolu'daki beyliklerin beyleri tarafından sürdürüldüğü görüşleri de mevcuttur. Anadolu beyleri, bu dönemde eser veren müellifleri Türkçe yazmaları konusunda teşvik etmişlerdir (Yelten, 2014, s. 211). Böylelikle bir yandan o dönemde kullanılan Türkçe hakkında fikir sahibi olunması, öte yandan da bu eserlerle Türk dilinin gelişim alanının rahatça takip edilebilmesi sağlanmıştır. 
Zeynep Korkmaz, Oğuz Türkçesi hakkında bilgi verirken Oğuzların bir yandan kendi sözlü kültürlerini yazıya aktarmak için uğraştıklarını bir yandan da Arapça ve Farsçanın kendi dillerinden üstün olmadığını kanıtlama çabasına girdiklerini açıklamaktadır (Korkmaz, 2011, s. 42). Selçuklular döneminde devlet erkânı bu iki dili resmî dil olarak kabul etmiş, Türkçe ise eğitim düzeyi düşük halk arasında konuşulan bir dil olmuştur. XIV. yüzyılla birlikte özellikle beylikler döneminde verilen eserlerin Türkçe olarak kaleme alınması, Anadolu'da bir Türkçecilik akımının başladığını gösteren önemli etkenlerden birisi olarak da görülebilir (Yavuz, 1999). Bu dönemde yazılan eserlerin dilleriyle ilgili Duman şu açıklamaları yapmaktadır (Duman, 2002, s. 122):

Kuruluş devresinden başlayarak Klâsik Osmanlı Türkçesi Devresi'ne kadar süregelen ve Eski Anadolu Türkçesi veya Beylikler Dönemi Türkçesi diye adlandırdığımı devre, dilin/Türkçenin bir anlaşma vasıtası olarak telakki edildiği ve bu anlayışa uygun eserlerin meydana getirildiği devredir. Gerek telif edilen gerekse tercüme yoluyla Türkçeye kazandırılan eserlerin dili bu dönemde halk kesiminin kolaylıkla anlayabileceği biçimde olabildiğince sadedir. Bazı kitap adları, dinî terimler ve kalıplaşmış ifadeler dışında yabancı gramer unsurlarına pek rastlanmaz. Dinî, felsefî konulu ve bilimsel pek çok eser eğitici maksatla kaleme alınmış olduğundan hedef kitlenin özellikleri dikkate alınarak yazılmışlardır. (...) Gerçi aynı dönem yazarları arasında Türkçe yazdığı için bir mahcubiyet içinde gözüken müellifler de yok değildir. Bunun sebebinin, Türkçenin o devrede henüz sanat dili olarak yaygınlık kazanmayıp "avam" dili sayılması olduğu anlaşılıyor.

XVI. yüzyıldan itibaren yoğun bir şekilde Arapça ve Farsça sözcük ödünçlemeleriyle birlikte Arapça ve Farsça dil bilgisi şekilleri de Türkçeye girmekteydi. Örneğin Türkçenin bilinen hiçbir döneminde dilbilgisel cinsiyet kategorisi bulunmamaktadır. Ancak Türkçede, Arapça ve Farsça isimlerin çoğulları da ödünçlendiğinden her iki dilden ödünçlenen tamlama şekillerinde tamlanan dişil ya da çoğul olduğunda tamlayan da dişil yapılmaktaydı: "efkâr-ı garîbe" tamlamasında fikir sözcüğünün çoğulu olan efkâr kullanıldığı için tamlayan da garîb yerine dişil yapılarak garîbe şekline sokulmuştur. Özellikle Arapçadan ödünçlenen sözcüklerde, sözcüğün kendisiyle birlikte o sözcüğün bütün ailesi de ödünçlenmiştir. Dolayısıyla bu tarz bir cinsiyet kategorisinin de Türkçede kullanıma girmesi kaçınılmaz olmuştur.

Şunu da belirtmekte fayda var ki bazı kesimlerin iddia ettiği gibi Osmanlı döneminde konuşulan dil Arapça, Farsça ve Türkçenin kırması bir dil değil, Arapça ve Farsça ödünçlemelerin yoğun olarak kullanıldığı bir dil olarak karşımıza çıkmaktadır. Bu sebeple Osmanlı topraklarında konuşulan dili müstakil kırma bir dil olarak adlandırmak yanlıştır (Develi, 2017). Şemseddin Sami (1850-1904) meşhur sözlüğü Kamûs-ı Türkî'nin önsözünde Arapça ve Farsça ödünçlemelerle ağdalı hâle getirilmiş dilin aslında Türkçe olduğunu, Arapça, Farsça ve Türkçenin karması bir dil olmadığını vurgulamaktadır (Şemseddin Sami, 
1317). Dolayısıyla o dönemde kullanılan dili Türkçeden ayrı düşünmek ilmî açıdan büyük bir yanlışlığa yol açacaktır.

1839yılında ilan edilen Tanzimat Fermanı bazı siyasî değişiklikleri beraberinde getirirken 1856 yılında ilan edilen Islahat Fermanı ile birlikte bu siyasî değişiklikler genişletilmiştir. Bu değişiklikler çalışmamızın konusu olan dil ile ilgili düşünceleri de kapsamaktadır. Islahat Fermanı ile birlikte dil reformu düşüncesinin filizlenmeye başladığını söylemek olasıdır (Lewis, 2007, s. 17). Türkçenin tarihî seyri içerisinde yukarıda açıklanan dil üzerine yakınmalar çoğunlukla bireyselken Tanzimat ile birlikte daha kurumsal bir dil reformu düşüncesi Osmanlı topraklarında filizlenmeye başlamıştır.

Türkçenin Osmanlı devleti sınırlarındaki resmî durumunun belirlenmesi adına önemli bir aşama olarak görülen Kanun-ı Esasî (1876) ile birlikte Türkçe resmî dil olarak kabul edilmiştir. Türkçenin resmî dil olarak tanınması Kanun-ı Esasî'nin 18. maddesinde şu şekilde açıklanmıştır (Sadoğlu, 2003, s. 97-98):

Hidemât-ı devlette istihdam olunmak için devletin lisân-ı resmîsi olan Türkçeyi bilmek şarttır.

Yukarıda iktibas edilen 1876 Anayasası'nın 18. maddesinin en önemli özelliklerinden biri de resmî dilin Lisân-ı Osmanî ya da Osmanlıca değil Türkçe olarak metinde yer almasıdır (Sadoğlu, 2003, s. 98-99). Aynı anayasanın 18. maddesinde de devlette işe girebilmek için devletin resmî dili olan Türkçeyi bilmek şartı getirilmiştir. Bu durum Sadoğlu tarafından ulusçuluk anlayışı bakımından oldukça önemli bir dönüm noktası olarak vurgulanmaktadır. Bu iki maddede de devlet, sınırları içerisinde yaşayan halkların anadillerine bir müdahalede bulunmazken kendi resmî dilini Türkçe olarak ilan etmekte ve resmî kurumlarda çalışmak isteyenlerin Türkçe bilmesini bir şart olarak ortaya koymaktadır. Kanun-ı Esasî'ye kadar üzerinde durulmayan resmî dil hususunun özellikle bu dönemde ortaya çıkması, matbaanın icadından sonra basılan kitap, gazete, mecmua gibi matbu malzemelerin bütün memleket sınırları içerisinde okunabilir olması ve okullarda okutulacak ders kitaplarının da idare tarafından izin verilip bastırılacak olması, konuşma dilinde olmasa bile yazı dilinde ölçünlü dil mecburiyetini de beraberinde getirmiştir.

Bahsi geçen dönemde düşünürler, yazarlar ve gazeteciler Türkçenin daha geniş kitleler tarafından anlaşılmasına gayret göstermişlerdir. Çünkü daha geniş kitlelere ulaşmak için yazı dili ile konuşma dili arasındaki farkı en aza indirmek önemli bir ihtiyaç hâline gelmiştir. İbrahim Şinasi (1824-71), Ziya Paşa (1825-80) ve Namık Kemal (1840-88) bu konu üzerinde yazılar kaleme almışlardır. Bahsi geçen devrin yenilikçi edebiyat ve siyaset adamlarının ardından, edebî açıdan etkili olan Servet-i Fünûn ve Fecr-i Âti dönemlerinde ise sanatçıların edebî bir tutum olarak sergiledikleri "soyut ve örtük anlatım" sebebiyle dilde sadeleşme kesintiye uğramıştır. 
Ahmet Midhat'ın da kurucularından biri olduğu ve Haziran 1908 yılında kurulan Türk Derneği, tarihimizde ilk milliyetçi kültür örgütü olmasına rağmen derneğin altmış üç üyesi dilin geleceği hakkında ortak bir görüşe sahip değildir (Lewis, 2007, s. 24). Bu hareketin dil üzerine görüşleri Lewis tarafından şu şekilde özetlenmektedir (Lewis, 2007, s. 24-25) :

Türkçe olmayan unsurların dilden temizlenmesini ve yerlerine halihazırdaki konuşma dilinde bulunan yerli kelimelerin koyulmasını isteyen sadeleştirmecilerdi. Bazıları, yeni kelimelerin kuralı Türkçe son eklerin yardımıyla üretilmesine ve halkın kullandığı Arapça ve Farsça kelimelerin Türkçe sayılması gerektiğine inanmış Türkçecilerdi. Bunların yanında Türkçecilerin ikinci noktada belirtilen görüşüne itiraz etmeyen fakat başat lehçelerden kelimelerin ve son eklerin alınmasını da savunan tasfiyeciler de vardı. Bazıları ise Farsça izafetin terk edilmesini dahi sindiremediler ve Osmanlıları Buharalılara çevirmek isteyenlere şiddetle karşı çıktılar.

Dilde sadeleşme amacıyla yola çıkılan bu hareket içerisindekiler bile kendi içlerinde bu sadeleşme konusu üzerine anlaşamamışlar ve bu grup dernek dışındakiler tarafından da tasfiyeciler olarak adlandırılmıştır. Bununla beraber yeni türetilecek sözcüklerin Türkçe eklerlerle yapılması, halkın kullandığı Arapça ve Farsça sözcüklerin Türkçe sayılması gerektiğine inanmış olan kesimin görüşleri bugünkü modern dilbilim anlayışıyla birebir benzerlik göstermektedir. Çünkü dile girmiş ve halk tarafından kabul görmüş her sözcük ya da unsur artık o topluma mâl olmuştur. Bu sebeple bu sözcüklere kaynak dilin malı olarak bakmak bir hata olacaktır. İngilizcenin en önemli sözlüklerinden biri olan Webster'da 156 adet Türkçe sözcük bulunmaktadır. Bu sözcükler incelendiğinde ise sadece çok az bir kısmının Türkçe kökenli olduğu göze çarpmaktadır. Fakat yabancı kökenli sözcükler Türkçe üzerinden İngilizceye geçtiklerinden bu sözcükleri sözlükte Türkçe olarak adlandırma yoluna gidilmiştir. Bu durum da açıkça göstermektedir ki halk tarafından kabul gören yabancı kökenli bir sözcük modern dilbilim anlayışına göre artık o toplumun söz varlığına ait olarak görülmektedir.

Yukarıda bahsedilen Türk Derneğinden daha fazla etki uyandıran bir edebiyat topluluğu ise Nisan 1911'de Selanik'te kurulan ve yayınladıkları dergiyle aynı adı taşıyan Genç Kalemler hareketidir. Yeni Lisancılar olarak da bilinen bu derneğin en önemli temsilcileri ünlü kısa hikâye yazarı olan Ömer Seyfeddin ve Ziya Gökalp'tır. Dilde sadeleşmenin manifestosu olarak görülen ve Ömer Seyfeddin tarafından kaleme alınan "Yeni Lisan" adlı yazıyı, derneğin bir başka üyesi olan Ali Canib şu şekilde açılamaktadır (Yılmaz, 2013, s. 9):

Hemen işe başladık. IIlk sayımız 29 Mart 1327 (1911)'de çıktı. Başmakaleyi, lisanda ihtilal beyannamesini "Yeni Lisan" unvanı altında Ömer Seyfeddin kaleme almıştı. Fakat imza koymamıştık. İstiyorduk ki davamız, bir şahsın eseri olarak görünmesin. Yazının sonunda kocaman bir istifham işareti (?) klişesi vardı ve bunu bize Ömer Seyfettin teklif etmişti. 
Ziya Gökalp de derginin Temmuz ayında yayınlanan sayısında önceki sayılardakine benzer dil görüşlerini şu şekilde açıklamaktadır (Argunşah, 2012, s. 240-241):

Avamla havas arasında bu iki muhalif cereyan müsademe ede ede bir zaman oldu ki artık güzellik zevki kati bir surette bilgiçliğe galebe geldi. Ve Yeni Lisan bu surette ilk numunelerini, ilk kaidelerini irâeye başladı. Yeni Lisan bilgiçleri memnun etmeyecektir. Çünkü bunlar birçok faydasız lügatler ve kaideleri ezberlemiş ve bu tahsil mümareseleri esnasında yabancı tecvitlere esirane bir surette ülfet etmiş bulunduklarından kaplumbağa kabuğundan çıkamadığı gibi bunlar da ananelerinden, itiyatlarından vazgeçemezler. Fakat demokratik bir memlekette ekseriyet hâkim olduğundan nihayet tabiilik, suniliğe galebe çalacaktır. Yeni Lisan bugün gençler tarafından terviç ediliyor. Yarın bütün Osmanlılar ve umum Türkler yalnız bu lisanda yazacak, bu lisanda okuyacaktır. Bir zaman gelecek ki Şinasi lisanında yazılmış kitaplar yeni lisana tercüme edilmedikçe okunamayacaktır. Bugün bile Yeni Lisanı kabul ve terviç eden gençler eski lisanda yazılmış eserleri okuyamıyor. Arapça, Acemce terkipleri, cemleri telaffuzdan iğreniyor. Mukavemet edenler eserlerini okunmamak için yazacaklar, inat ve ısrar gösterenler Irfan Paşaların tarihî akranları olacaklardır. (Genç Kalemler, Temmuz 1911)

Ziya Gökalp ağdalı Türkçe kullananlara karşı çıkmıştır. Onun yerine halkın kullandığı Türkçenin konuşulupyazılması gerektiğini belirterek bu dili YeniLisan, sanat kaygısı ileağdalı yazanların dilini ise Eski Lisan olarak adlandırmıştır. Yeni nesiller tarafından kendisinin Yeni Lisan diye adlandırdığı dile rağbetin oldukça yüksek olduğu ve yakında bütün Osmanlı́nın da bu dili kullanacağı Ziya Gökalp tarafından iddia edilmektedir. Gökalp’a göre Eski Lisan’la yazanlar gereksiz sözlük karıştıran ve Arapça-Farsça terkiplerde boğulmuş kişilerdir. Bu eski lisancıların kullandıkları dil de Türkçe olmaktan uzak bir dildir. Gökalp Türkçülüğün Esasları isimli eserinde, Türkçeyi ıslah/sadeleştirme için bütün Arapça ve Farsça sözcükleri atmaktan ziyade Arapça ve Farsça dilbilgisel kuralları terk etmeyi ve yine Türkçe karşılığı bulunan Arapça ve Farsça ödünçleme sözcüklerin dilden çıkarılmasını önerirken Türkçesi bulunmayan sözcüklerin ise dilde yaşamaya devam etmesinin gerekliliğini vurgulamıştır (Gökalp, 1923, s. 12). Bu bahsettiği hususları Genç Kalemler'de yazdığı Lisân şiirinde de görmekteyiz. Halk tarafından kabul görmüş ödünçleme sözcüklerin Türkçe sayıldığını "Türkçeleşmiş Türkçedir" şeklinde açıklamaktadır. Bu sözcüklerin yerine uyduruk sözcük üretilmesine yine bu şiirinde karşı çıkmaktadır. Genç Kalemler dergisinde yer alan dil görüşleri yukarıda bahsettiğimiz gibi modern dilbilimin kurallarına ve dilin doğal seyrine uygun bir yaklaşım olarak karşımıza çıkmaktadır. Bununla birlikte Ziya Gökalp'ın bilgiçler olarak tanımladığı kesimin zorlama sözcük seçimleri ve kullandıkları terkipler dili anlaşılmaz hâle getirmiştir. Hem sözcüklerin öz Türkçe olması hususundaki zorlamalar hem de dili başka dillerden alıntı sözcük ve terkiplerle ağdalı hâle getiren yaklaşım dilin doğal seyrine olduğu kadar modern dilbilim anlayışına da zıt bir uygulamadır. 
Cumhuriyet'in ilânından önce ortaya konan son sadeleşme hareketi ise "Tedkikât-ı Lisâniye Encümeni" olarak adlandırılan bir kurumun ihdâsıdır. Balcı bu hareketi Türk Dil Kurumunun atası olarak kabul etmekte ve bu kurumun kuruluş gerekçesini şu şekilde açıklamaktadır (Balcı, 2018):

Osmanlı Arşivleri Maarif Nezareti evrakı arasında korunan vesikalarda 1. Dünya Savaşı yıllarında yazılmış birtakım belgelerde Tedkikat-ı Lisaniye Encümeninin kuruluşuna, teşkilat şemasına, çalışanların alacağı maaşlara kadar ayrıntılı bilgilerin bulunduğu görülmektedir. Maarif Nezaretine bir Tedkikat-ı Lisaniye Encümeni kurulması için uzun gerekçeleri ve nasıl teşkilatlanacağını, nasıl çalışacağını ihtiva eden bir ariza ile başlayan yazışmalar, tavsiye edilen teşkilatın kuruluşunu, az da olsa çalışmaları hakkında önemli bilgiler vermektedir... Yazışmaların ilkiAliKemalBeyeaittir. AliKemalBey, 01 Şubat 1332 tarihindekaleme aldığı "Huzûr-ı Sâmî-i Nezâret-penâhî̀ye arîza-i husûsiyye-i kemterâne"sinde konuya farklı bir açıdan yaklaşır ve bu üç encümenin tertip ve düzene alınmasıyla beraber bir de Edebiyat Encümeni kurulması gerektiğini belirtir:

"Sarf ve imlâ encümenlerinin ikmâl-i teşkilatıyla beraber lugat encümeninin tensîki ve ayrıca bir edebiyât encümeni teşkili ehemm ve elzemdir."

\section{Cumhuriyet Dönemi Dil Tartışmaları}

Enver Paşa'nın gayretleriyle üretilen ve Arap harflerini birleştirmeden yazarak ve hecede bütün ünlüleri gösteren yazı denemesi Mustafa Kemal'in ilgisini çekmekle birlikte, bu deneme zamansız ve yetersiz bulunmuştu. Nitekim imlâ kolaylığı oluşturma amacıyla ortaya atılan bu yazı türü matbuatta ve kamuoyunda pek tasvip edilmemiş ve olumlu hiçbir sonuç doğurmamıştır (Ünaydın, 1954, s. 28).

Cumhuriyet'in ilanından sonra Mustafa Kemal, İstanbul basınının temsilcileri ile bir toplantı yapmıştır. Bu toplantıya katılanlardan Hüseyin Cahit, Atatürk'e "Neden Latin alfabesini kabul etmiyorsunuz?" diye bir soru yöneltince Atatürk "Henüz sırası değil." şeklinde bir yanıt vermiştir. Atatürk'ün bu cevabının nedenini Lewis, söz konusu dönemin Birinci Meclis dönemi olduğu ve vekiller arasında meslekleri din adamlığı olan elli civarında hoca ve bunlara ek olarak sekiz tarikat şeyhi ile mesleklerini aşiret reisliği olarak tanımlayan beş kişi bulunduğu hatırlanırsa anlam kazanır (2007, s. 42) şeklinde açıklamaktadır.

25 Mart 1924'te TBMM'de söz alan İzmir Milletvekili Şükrü (Saraçoğlu) Bey, okumayazma konusuna değinerek Arap harflerinin Türk dilini yazmaya uygun olmadığını, halkın okuma-yazma oranının düşüklüğünün sebebinin Arap harfleri olduğunu, İslâm dininin okumayı teşvik eden bir din olduğu hâlde harfler yüzünden halkın okuyamadığını ve bunun büyük bir dert olduğunu beyan edip Maarif Vekâletinin konu hakkındaki tavrını sormuştur. Fakat mecliste kendisine yönelik ağır eleştiriler yapılmıştır (Tongul, 2004, s. 114). 
Şubat 1923'te düzenlenen İzmir İktisat Kongresi'nde üç işçi delegesi Latin harflerinin kabulü yolunda bir önerge teklif ettiler. Kongreye başkanlık eden Kazım Karabekir, İslâm'ın birliğine zarar vereceği gerekçesiyle bu öneriyi uygunsuz bulmuş ve konu hakkında şu sözleri sarf etmiştir (Lewis, 2007):

Derhal bütün Avrupa'nın eline güzel bir silah vermiş olacağız, bunlar âlem-i islâma karşı diyeceklerdir ki Türkler ecnebi yazısını kabul etmişler ve Hıristiyan olmuşlardır. İşte düşmanlarımızın çalıştı̆ı̆ şeytankârane fikir budur.

Kılıçzade Hakkı gibileri ise alfabenin dinle bağdaştıılamayacağını belirterek bu gibi görüşlere karşı çıkmışlardır.

\section{Harf Devrimi}

1353 sayılı "Yeni Türk Harflerinin Kabul ve Tetkiki Hakkında Kanun" ile Harf Devrimi Türkiye Cumhuriyeti tarafından 1 Kasım 1928 yılında kabul edilmiştir. 26 Haziran 1928 yılında Harf Devrimi'nin gerçekleşmesi için Falih Rıfkı (Atay), Ruşen Eşref (Ünaydın), Yakup Kadri (Karaosmanoğlu) ve Fazıl Ahmet (Aykaç) gibi isimlerden oluşan "Dil Encümeni" alfabe ve dilbilgisi kolu olarak ikiye ayrılmış ve Atatürk de her iki grubun toplantılarına fırsat buldukça katılmıştır (Lewis, 2007, s. 43).

Bahsi geçen bu komisyonlarda yapılan görüşmeler sonucunda Latin harflerinden oluşan Türk alfabesinin kabul edilmesi hususunda karar alınarak 41 sayfa hacminde bir alfabe raporu hazırlanmıştır. Bu mufassal raporda Türk dilindeki seslerin özellikleri, Türkçeye mahsus Latin harflerinin seçilmesi ve bu hususta tatbik olunması gereken esaslar, muhtelif alfabelerdeki çift harfler, işaretli harfler ve bunların Latin alfabesine eklenmiş harfleri, Türk alfabesini teşkil eden harflerin çeşitli dillerdeki karşıılıkları, tespit edilen yeni alfabenin vasıfları vb. belirlenmiştir. Falih Rıfkı tarafından Mustafa Kemal'e takdim edilen bu raporun sunumu sırasında meydana gelen konuşmayı Falih Rıfkı şöyle anlatmaktadır (Yılmaz, 2013, s. 41):

Atatürk bana sordu: 'Yeni yazıyı tatbik etmek için ne düşündünüz?' 'Bir on beş yıllık uzun, bir de beş yıllık kısa mühletli iki teklif var.' dedim. 'Teklif sahiplerine göre ilk devirleri iki yazı bir arada öğretilecektir. Gazeteler yarım sütundan başlayarak yeni yazılı kısmı artıracaklardır. Daireler ve yüksek mektepler için de tedrici bazı usuller düşünülmüştür.' Yüzüme baktı. 'Bu ya üç ayda olur, ya hiç olmaz' dedi. Hayli radikal bir inkılâpçı iken ben bile yüzüne bakakalmıştım: 'Çocuğum,' dedi, 'gazetelerde yarım sütun eski yazı kaldığı zaman dahi, herkes bu eski yazılı parçayı okuyacaktır. Arada, bir harp, bir iç buhran, bir terslik oldu mu, bizim yazı da Enver'in yazısına döner. Hemen terk olunuverir.

Dil politikası uygulamaları bir seferlik olabileceği gibi problemlere kısa süreli çözümler getirebilir veya uzun süreli amaçları benimseyebilir (Gramley ve Kummer, 2008, s. 298). Bu 
tanımdan ve yukarıdaki pasajdan da açıkça anlaşılacağı üzere Atatürk için yeni alfabenin halk tarafından kabul edilmesi ve benimsenmesi, çabuk öğrenilmesi büyük önem arz etmekteydi. Bu yüzden Atatürk, bu alfabenin halka öğretilmesi için halk gezileri yapmıştır (Başçetinçelik, 2018).

Hükûmet tarafından birçok yönetmelik bu yeni alfabenin öğretilmesi için yayınlanmıştır. Bunlardan en ilginci de Arap harfli yazı ile devlet kurumlarına dilekçe yazan kişilerin dilekçelerinin okunmadan doğrudan yırtılacağına dair yönetmeliktir (Yılmaz, 2013, s. 44):

\section{Anadolu Ajansına}

Başvekâletten

Bazı kimselerin resmî makamlara ve zevata eski harflerle yazılı müracaatlarda bulundukları görülmektedir. Mezkûr harflerle gerek Başvekâlet makamına ve gerek zâta gönderilecek yazıların okunmadan yırtılıp atılacağı herkesçe bilinmek üzere beyan olunur.

Harf Devrimi'nin nasıl gerçekleştiği Mustafa Canpolat tarafından şu sözlerle açıklanmaktadır (Canpolat, 1979, s. 22-23'den akt., Tongul, 2004, s. 117):

1862 dolaylarında başlayan ve oldukça uzun bir serüven geçirdikten sonra, Cumhuriyet dönemine değin gelen Latin harfleri konusu, Atatürk'ün işe el koymasıyla, çok kısa bir süre içerisinde çözüme ulaşmıştır. Daha önce olabilir miydi? sorusu akla gelebilir. Yanıtım, olamazdı biçiminde olacaktır. Yazı değişimi gerçekte Atatürk devriminin bir parçasıdır. Laiklik ilkesi benimsenmeden bir yazı değişikliği yapılamazdı. Çünkü hayatımızda köklü değişiklikler yapılmadan bir yazı değişikliği yapılamazdı. Ulusçuluk akımı gelişmeden bir yazı değişikliği yapılamazdı. Kısacası Cumhuriyet kurulup Atatürk ilkeleri birer birer kurumlaşmaya başlamadan bir yazı değişikliği yapılamazdı.

Yukarıdaki alıntıda Canpolat, bir harf devriminin yapılabilmesi için yeniliğe ve değişime açık bir iktidarın bulunması gerekliliğini vurgulamaktadır. Cumhuriyet'in kendisini ispatlama çalışmalarının önemli bir unsuru olarak tarihe geçen "Harf Devrimi" yeni kurulan rejimin söz konusu çalışmalar içerisinde gerçekleştirdiği en önemli devrimlerden biri olarak tarihteki yerini almıştır. Tongul da buna benzer bir yorumu Harf Devrimi'nin gerekliliğini açıklarken şu sözlerle belirtmektedir (Tongul, 2004, s. 129):

Atatürk, Türk milletinin, uygar milletler arasına girmesini kolaylaştırmak ve bunu sağlamak için yeni Türk alfabesinin kabulünü zorunlu görmüştür. Çağdaş uygarlığa giden yolu Türk milletine açmak, onun çağdaş uygarlık seviyesinin üstüne çıkmasını sağlamak amacının yanısıra, alfabe değişikliğinin diğer büyük amacı da millîleşmek, millî kültürümüzü oluşturmaktır. 
Atatürk sonrası İsmet İnönü döneminde de Türk Dil Devrimi'nde aşırı sadeleştirme/ özleştirme/arılaştırma gibi adlarla anılan öz Türkçe faaliyetleri devam etmiştir. Ancak bu politikalar eğitimciler ve aydınlar tarafından tepkiyle karşılaşmıştır. Türkiye çok partili hayata geçtikten sonra dildeki öz Türkçe eğilimi azalmış, dil kendi akışı içerisinde, yani olması gerektiği seyrinde gelişmiş̧tir.

\section{Amerika Birleşik Devletleri'nde Dil Politikası ve Planlaması}

Bu bölüme başlarken Amerikan Dil Planlaması ile Türk Dil Devrimi'nin birbirleriyle aynı amaçlar için gerçekleştirilmiş uygulamalar olmadığını belirtmekte fayda var. ABD'de Türkiye'de olduğu gibi büyük reformist bir hareket ile karşılaşmamaktayız. Wiley'e (1999) göre "Amerikan dil politikası ve planlaması her zaman resmî bir dil açıklamaktan kaçınır görünmektedir". Böyle bir kanıya rağmen yine de Amerika Birleşik Devletleri'nin bir dil politikası olduğu, dil planlamasının iki biçimde ve alanda uygulandığı alan araştırmalarından ortaya çıkmaktadır. Bunlar Avrupa'dan gelen, farklı dil konuşan göçmenlere yönelik ve Amerikan Devleti'nin kolonileştirmek suretiyle kendi topraklarına kattığı, farklı dil konuşan toplumlara yönelik olarak belirtilebilir. Örneğin Kloss (1977/1998) Amerikan tarihindeki Avrupalı göçmenlere yönelik yapılan sistemli çalışmaları karşılaştırmalı olarak sunmaktadır. Ona göre, Amerikan Devleti'nin Avrupalı göçmenlere yönelik dil politikası genel olarak hoşgörü odaklı vezaman zaman da ana dillerinin kullanımını̈̈zendiriciodaklıdır. Bu duruma bir örnek verecek olursak, 1892-1954 yılları arasında yaklaşık 12.000.000 göçmenin Amerika'ya kabulünden önce çeşitli bürokratik işlemlere tabi tutuldukları Ellis Adası'nda bulunan Göç Müzesindeki iki adet posterde dil planlamasının Amerika'da ne şekilde işlediği görülmektedir. Aşağıda görselleri kullanılan posterlerin ilkinde, bu ülkeye göç edenlerin Amerika'nın dilini öğrenmek için devlet okullarına ya da kütüphanelerdeki ücretsiz öğleden sonra veya akşam İngilizce kurslarına gitmelerinin Amerikan vatandaşlığına hazırlık olacağı vurgulanmaktadır. Yani bu göçmenlere tek bir ulus olabilmenin ana şartının İngilizce öğrenmek olduğu uyguladıkları eğitim programları ile gösterilmektedir. Aynı şekilde ikinci posterde, İngilizce öğrenmenin Amerika'da daha iyi yaşam şartları, daha iyi bir ev, daha iyi bir iş ve çocuklara daha iyi bir gelecek sağlayacağı vurgulanmaktadır. Ana dil olarak İngilizceyi benimseyen bireylerin daha iyi bir Amerika meydana getirecekleri de belirtilmektedir. Aşağıdaki posterler, Ulusal Amerikanlaştırma Komitesi ve Amerikan Eğitim Bürosu tarafından hazırlanmıştır. Dolayısıyla bu şekilde bir dil planlaması yaparak gelen göçmenlerin Amerika'ya entegrasyonlarının sağlanması ve bu göçmenlerden ulus olarak en üst düzeyde yararlanmak amaçlanmıştır. Bu durumun, dil politikalarının bir ülkede entegrasyonun en önemli parçalarından biri olması bakımından büyük önemi bulunmaktadır. 

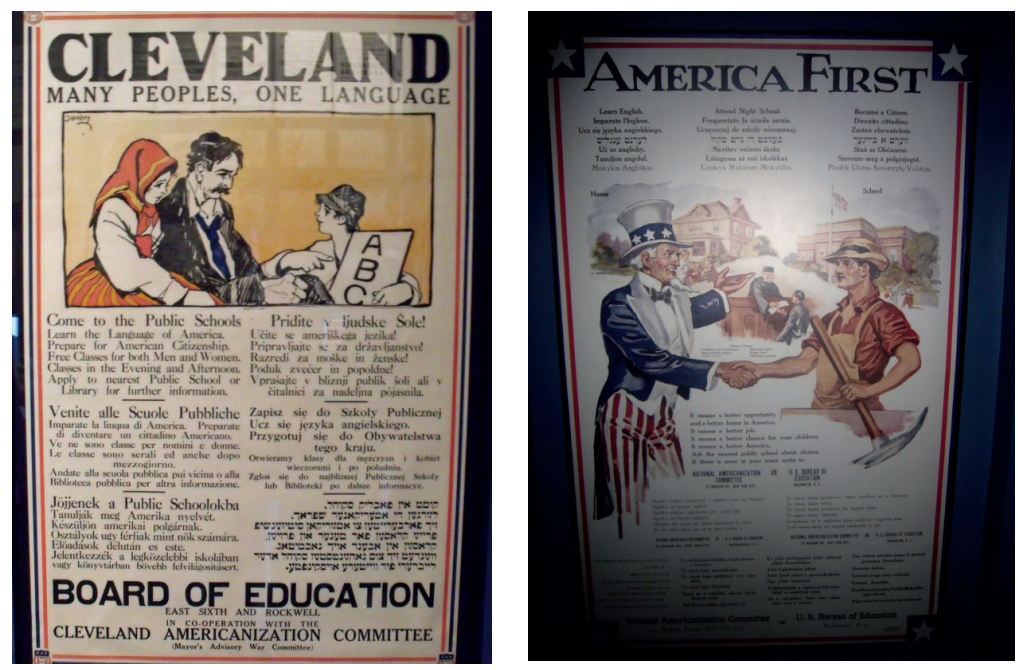

Tablo 1: Ellis Adası'nda bulunan Dil Planlaması ile alakalı afişler.

Bunlara ek olarak karşılıklı çıkarlar söz konusu olduğundan, Avrupalı göçmenlerin toplumsal katılımını arttırmak için İngilizceye yumuşak geçişin sağlanması amacıyla çift dilli eğitime, iki dille yazılmış oy pusulalarına ve mahkemelerde çevirmen sağlanmasına izin verilmiştir. Dahası hoşgörü odaklılık kapsamında yeterli kaynakları olduğu takdirde Avrupalı göçmenlere kendi dillerini koruma ve konuşma özgürlüğü de tanınmıştır. Ancak 1. Dünya Savaşı sırasında toplumsal, politik ve ekonomik yararlar gözetildiğinden baskın dil olan İngilizcenin kullanılması için daha sınırlayıcı kanunlar çıkarılmıştır. Bunlar 1960'lara kadar etkilerini sürdürmüş, 80'lerden sonra ise sınırlayıcılık ve korumacılık daha da artmıştır. Bazı durumlarda ise baskı odaklı kanunlarla azınlık dillerinin kullanılması engellenmiş, bu durum da dilsel ve etnik ayrımcılığa sebep olmuştur.

Heath gibi bazı araştırmacılar, Amerikan Devleti'nin daha sonra Amerikan toprağı olacak Meksika'daki Kastilya ve Peru sömürgelerinde uyguladığı dil politikaları ve planlamasını araştırmıştır (Heath, 1976, s. 51). Ona göre İngilizce dilinin yerleştirilmesi için merkezi olmayan bir yaklaşım izlenmiştir ve oradaki çalışmalar "dil durumu başarısı"dır, yani "siyasi sürecin politik, ekonomik ve sosyal işlerini yürütenler için bir hükümetin kabul edilebilir dil ile ilgili kararlarının meşrulaştırılmasıdır". Crawford, Amerika Birleşik Devletleri'nde politika oluşturmanın, sömürge yönetimi durumları dışında büyük ölçüde merkeziyetçi olmayan ve hoşgörü odaklı olduğunu belirtmiştir (Crawford, 1995). Leibowitz ise ABD Federal Hükûmeti'nin sadece "sömürge" bağlamında değil, bölgesel politika yönetiminin bir parçası olarak dil politikalarını dayatma tarihine sahip olduğunu belirtmektedir. Örneğin, federal kontrol altındaki yerli halklara uygulanan okullaşma politikalarının yönetiminde bunlara rastlamak olası bir durum olarak karşımıza çıkar. Leibowitz, ilk önce dil politikalarının sosyal kontrol araçları rolüne odaklanmaktadır. Sonra da resmi dil olarak İngilizce politikalarının ve kısıtlayıcı dil politikalarının toplumsal, politik, ekonomik ve eğitimsel anlamda çeşitli dilsel azınlık grupların 
üzerindeki etkisini analiz etmektedir. Leibowitz'in vardığı sonuç ise İngilizcenin resmî dil olarak dayatılmasının, azınlıkların dil, renk ve dinlerine yönelik baskı unsurlarından bir tanesi olduğudur.

Schmidt, 1960'lara kadar İngilizcenin, kullanılan "ağız" ve okuryazarlık gerekliliklerinin bireylerin göç etmelerini, oy kullanmalarını ve iş aramalarını engelleyen ayrımcılık noktaları olarak kullanıldığını belirtmektedir (Schimidt, 1995). Bunun yanı sıra tek dillilik olgusunun da ABD'de özellikle evrensel, doğal ve ideal koşul olduğu tarihsel olarak ön kabul gördüğü vurgusu yapılmaktadır (Huebner, Davis ve Lo, 1999, s. 26). Bundan dolayı göçmenlere karşı asimilasyon ve olumsuz bakışın olduğu kanısına varmak çok zor değildir. Bu görüş çerçevesinde ABD'ye göç edenlerin kendi dillerini bırakmaları, sadece İngilizce konuşmaları, ekonomik kazançlarını artırma ve genel toplumsal kabul görmeleri için baskın dili konuşmaları gerektiği belirtilip, azınlık dili ve kültürü korunursa bunun toplumdan uzaklaşmaya ve izolasyona yol açacağı için ulusal birliğe sekte vuracağı iddiaları ortaya atılmıştır (Kloss, 1971, s. 250-268'den akt., Huebner ve Davis ve Lo, 1999, s. 26). Bu ideoloji özellikle 1. Dünya Savaşı yıllarında ABD'de üstünlük sağlamış, bu dönemde Almanca ve diğer dilleri konuşanlar aşağılanmış, Amerikalılaşma ve milliyetçilik üstün kılınmıştır.

Bu dönemdeki dil milliyetçiliği ideolojisinin bir etkisi de okuryazarlık üzerinde kendini göstermiştir. Wiley, bu konudaki görüşleri şöyle özetlemiştir: 1. İngilizce ve İngilizce okuryazarlık, diğer diller tarafından tehdit edilmektedir; 2. İngilizce okuryazarlık ABD'deki dikkate değer tek okuryazarlıktır; 3. İngilizce okuryazarlık oranları düşüktür çünkü bugünün göçmenleri geçmiştekiler kadar öğrenmeye istekli değillerdir; 4. Dilsel azınlıkların çoğu tek İngilizce politikalarını desteklemektedir; 5. İngilizce okuryazarlığı geliştirmenin en iyi yolu dilsel azınlık içerisinde yer alan çocuk ve yetişkinleri sadece İngilizce eğitimine yöneltmektir (Wiley, 1996). Bu görüşler, Afrikalı-Amerikalılara karşı farklı bir şekilde gelişmiştir. Örneğin, bu dönemde azınlıklar genellikle İngilizce öğrenmeye ve İngilizce okuryazarlığa yönlendirilirken köleleştirilmiş Afrikalı-Amerikalılar tam tersine okuryazarlıktan zorunlu yasalarla men edilmişlerdir, dahası bu yasalar onların okuma ve yazmayı öğrenmesini yasaklamaktadır (Schimidt, 1995, s. 5). Bu da gösteriyor ki ABD dil politika ve planlaması, farklı etnik gruplara farklı bir biçimde uygulanmaktadır. Buna göre Avrupalı göçmenlere yönelik politikalar daha çok "bütünleşmeye" (integration) yönelik yapısal asimilasyon olarak uygulanırken, Afrikalılara yönelik dil politikası bir nevi "evcilleştirme"ye (domestication) yönelik davranışsal asimilasyon olarak uygulanmıştır (Huebner, Davis ve Lo, 1999, s. 28). Bu olguyu Schmidt şöyle özetlemektedir:

Illk olarak, eğitim için vergilendirilmelerine rağmen Avrupalı Amerikalılar'dan başka bütün gruplar genişleyen kamu eğitiminin faydalarına çok daha yavaş ve zorlu süreçlerden sonra ulaştı. Ikincisi, eğitim onlara, genellikle ayrıştırılmış ve zayıf okullar aracılığıyla ulaştı. Üçüncü olarak, grupların kültürleri ve dilleri kamu eğitimcileri ve diğer toplum liderleri ve toplulukları tarafından aşağılandı 
ve buna göre, kültürel miraslarını sürdürme fırsatları devlet okulları aracılığıyla reddedildi. Ve dördüncü, toplumdaki egemen grup tarafindan reddedilme ve dışlama gibi bu görünür biçimler karşısında bile, verilen eğitim sadece "asimilasyon" odaklıydı (Schimidt, 1995, s. 5).

ABD'de uygulanan dil politikaları ve planlamada bazı topluluklara yönelik ayrımcılı̆ı̆ın bir diğer örneği de Yerli Amerikalılara karşı olan uygulamalardır. İngiliz yerleşimciler, Amerika kıtasına gelmeden önce burada 1000'e yakın yerli dil olduğu düşünülmektedir, bu sayı Avrupalı yerleşimciler geldikten sonra hastalıklar ve fetihler gibi çeşitli sebeplerle çok azalmıştır. Spicer, ABD bağımsız bir ülke olarak kurulduktan sonra Yerlilere yönelik 5 girişim olduğunu vurgulamaktadır (Spicer, 1980, s. 114-122):

1. Ayrilık ( 1870 'lerde İngiliz sömürge yönetimi sırasında başlayan)

2. Zorla Asimilasyon (1880'den 1930'lara kadar)

3. Kabile Restorasyonu: Faz I (1930'lardan 1950'lerin başına kadar)

4. Fesih (1950'den erken 1960'lara kadar)

5. Kabile Restorasyonu: Faz II (1960'ların ortalarından ileriye)

Bu dönemlerde birçok değişiklik yer almaktadır. Örneğin Ayrılık döneminde Yerliler ayrı bir toplum olarak kabul edilmiş ve onlarla anlaşmalar imzalanmış, okuryazarlık ile ilgili gelişmeler olmuşsa da Zorla Asimilasyon döneminde gösterilen ayrımcılıkla birlikte okuryazarlık gerilemiş ve Yerliler aşağı görülmüştür. Kabile Restorasyonu döneminde Ayrılık dönemindekine benzer gelişmeler olmuş ve okullar açılmıştır. Ancak gösterilen ayrımcılıklar nedeniyle kazanımlar elde edilememiştir. Diğer dönemlerde de benzer uygulamalar olmuş, okullar açılmış ancak oy verme, kültürlerini ve topraklarını koruma gibi hakların gelişmemesi sonucu tatmin edici sonuçlar elde edilememiştir. 1990'da Yerli Amerikan Dilleri Kanunu (Native American Languages Law) ile ilerleme sağlanmış ancak eski uygulamaların etkisiyle kazanımlar ve gelişmeler Yerli toplumlarda sınırlı etki yaratımıştır.

Amerikan Dil Politikası ve Planlaması 4 döneme ayrılmaktadır, bunlar ise şu şekilde özetlenebilir (Huebner, Davis ve Lo, 1999, s. 29; Leibowitz, 1974, s. 5-6):

1. 1789 'dan 1880 'e kadar, İngilizcenin resmî dil olarak tanımlanmadığı ve diğer dillerin kullanımına yönelik geniş bir hoşgörünün olduğu dönem.

2. 1880 'den 1920 'ye kadar ve daha sonra 2. Dünya Savaşına kadar, Ingilizcenin resmî dil olarak kabul edildiği, dil gereksinimlerinin net kullanımı ile devlet ve federal düzeyde azınlık ve göçmen gruplarına yönelik dışlama ve ayrımcılık dönemi.

3. II. Dünya Savaşı'yla (özellikle 1960 'larda) 1980 'lerin başına kadar, kısıtlayıcı dil gereksinimlerine yönelik bir rahatlama ve hatta diğer dillerin kullanımının teşvik edilmesi (1980'lerin ortalarına kadar); ve

4. 1980 'lerden günümüze, kısıtlamaya geri dönme eğilimi dönemi. 


\section{SONUÇ}

Kullanılan dilin ya da dillerin resmî bir idare tarafından dil-içi farklılıklar ile ilgili problemlerin çözülmesi için bilinçli bir şekilde düzenlenmesi faaliyeti olarak tanımlanabilecek "Dil Planlaması" bu makalenin konusu olan Türk Dil Devrimi'nde ve ABD tarafından iki farklı dönemde gerçekleştirilen dilsel tasarruflarda karşımıza çıkmaktadır. Her iki ülke tarafından dile yapılan müdahalelerin bazı yönlerden benzerlik taşımakla birlikte birbirlerinden önemli ölçülerde ayrıldıkları da görülmektedir. ABD'de yapılan dil planlamasında Avrupalı göçmenlerin toplumsal katılımını arttırmak için İngilizceye yumuşak geçiş amacıyla çift dilli eğitime, iki dilde yazılmış oy pusulalarına ve mahkemelerde çevirmen sağlanmasına izin verilmiştir. Türkiye'de ise Atatürk, Falih Rıfkı'nın gazetelerin hem Arap hem de Latin harfli beraber yayınlanması önerisine "Çocuğum, gazetelerde yarım sütun eski yazı kaldığı zaman dahi, herkes bu eski yazılı parçayı okuyacaktır. Arada, bir harp, bir iç buhran, bir terslik oldu mu, bizim yazı da Enver'in yazısına döner. Hemen terk olunuverir." diyerek karşı çıkmıştır. Yani ABD'nin uyguladığı yumuşak geçiş politikası Atatürk tarafından Dil Devrimi'ni baltalayacağı gerekçesiyle reddedilmiştir. Bununla birlikte Yerli Amerikalılara karşı uygulanan dil politikası Türk Dil Devrimi'ndeki sürece benzer bir biçimde daha katı olarak uygulanmıştır. Türkiye'deki dil devrimi toplumu bütünleştirmeye, devlet organizmasına dâhil etmeye yöneliktir. Türkiye'de azınlık statüsüne sahip gayrimüslimlerin okullarında kendi dillerini öğrenme imkânları bulunmakta iken ABD'de yerlilere karşı uygulanan dil politikası onları asimile etmeye ve dışlamaya yöneliktir. II. Dünya Savaşı'ndan sonra bu dilsel baskı bütün azınlıklara ve farklı dil konuşan topluluklara karşı uygulanmıştır. Türk Dil Devrimi yukarıda da belirttiğimiz üzere sadece dilde sadeleşmeyi içermemektedir. Bunun yanında Arap harflerini terk edip yeni bir alfabe olan Latin alfabesine geçişi de içermektedir. Amerikan Dil Planlaması ise daha çok bünyesindeki farklı dil konuşurlarını İngilizce potasında eritip birleştirmeye yönelik yapılmıştır. Her iki dil planlaması örneğinde de okur-yazarlığın geliştirilmesi ana amaçlardan biri hâline gelmiştir. Lâkin Afrikalı-Amerikalı azınlıklar haricindekiler genellikle İngilizce öğrenmeye ve İngilizce okuryazarlığa yönlendirilirken, köleleştirilmiş Afrikalı-Amerikalılar tam tersine okuryazarlıktan zorunlu yasalarla men edilmişlerdir. Türk Dil Devrimi'nin yapılışı hususunda iddia edilen nedenlerden biri halkın okuryazarlık oranının artırılmasına yönelik olmasıdır. Avrupalı göçmenlere yönelik politikalar daha çok "bütünleşmeye" (integration) yönelik yapısal asimilasyon olarak uygulanırken, Afrikalılara yönelik dil politikası bir nevi "evcilleştirme"ye (domestication) yönelik davranışsal asimilasyon olarak uygulanmıştır. Türk Dil Devrimi ise doğrudan bütünleştirmeye odaklanmıştır.

\section{KAYNAKÇA}

Argunşah, M. (2012). Dil ve edebiyat yazıları. İstanbul: Kesit Yayınları.

Balcı, M. (2018, Eylül). Türk Dil Kurumunun atası: Tedkikât-ı Lisâniye Encümeni. Birinci Dünya Savaşının 100. Yılında Savaş ve Toplum -Eve Dönen Asker- Kongresi, İstanbul. 
Başçetinçelik, A. (2018). Atatürk ve Dil Çalışmaları. http://turkoloji.cu.edu.tr/ATATURK/arastirmalar/ ayse_bascetincelik_ataturk_ve_dil_calismalari.pdf. adresinden edinilmiştir

Caferoğlu, A. (2000). Türk dili tarihi. İstanbul: Enderun Kitabevi.

Canpolat, M. (1979). Türkiye'de Yazı Devrimi Girişimleri. Yazı devrimi içinde (22-32). Ankara: Türk Dil Kurumu Yayınları-456.

Crawford, J. (1995). Bilingual education: History, politics, theory, and practice (3rd ed.).

Çiçekler, A. N. ve Kaçar, M. (2018). Ruhun yolculuğu. İstanbul: Büyüyen Ay Yayınları.

Develi, H. (2017). Osmanlı́nın dili. İstanbul: Kesit Yayınları.

Duman, M. (2002). Yenileşme döneminde Türk dili. Türkler Ansiklopedisi içinde (C. 15, s. 102-130). Ankara: Yeni Türkiye Yayınları.

Gökalp, Z. (1923). Türkçülüğün esasları. Ankara: Matbuat ve İstihbarat Matbası.

Gramley, S., \& Kummer, W. (2008). Language planning and policy. In S. Gramley \& V. Gramley (Eds.), Bielefeld introduction to applied linguistics (pp. 291-300). Biefeld, DE: Aisthesis Verlag.

Hakan, A. (1982). Dünyada ve Türkiyede akademilerin tarihçesi ve bugünkü durumu. Ankara Üniverstiesi Eğitim Bilimleri Fakültesi Dergisi, 15(2), 221-238.

Heath, S. B. (1976). Colonial language status achievement: Mexico, Peru, and the United States. In A. Verdoodt \& R. Kjolseth (Eds.), Language and sociology (pp. 49-91). Louvin: Peters.

Huebner, T., Davis, K. A., \& Lo, B. J. (1999). Sociopolitical perspectives on language policy and planning in the USA. Amsterdam: J. Benjamins.

İmer, K. (2001). Türkiye'de dil planlaması: Türk dil devrimi. Ankara: Kültür Bakanlığı Yayınları.

Joan, R. (1971). Evaluation and language planning. In J. Rubin \& B. H. Jernudd (Eds.), Can language be planned? Sociolinguistic theory and practice for developing nations (pp. 297-302). US: East West Centre.

Kloss, H. (1998). The American bilingual tradition (2nd ed.). Washington, DC: Center for Applied Linguistics and Delta Systems.

Köprülü, M. F. (1928). Millî edebiyat cereyanının ilk mübeşşirleri ve Divan-ı Türkî-i Basit. İstanbul: Devlet Matbaası.

Leibowitz, A. H. (1974, August). Language as a means of social control. Paper presented at the VIII World Congress of Sociology, University of Toronto, Toronto, Canada. Abstract retrieved from https:// files.eric.ed.gov/fulltext/ED093168.pdf

Lewis, G. (2007). Trajik bir başarı Türk dil reformu (M. F. Uslu, Çev.). İstanbul: Paradigma Yayıncılık.

Lo, B. J. (2010). Language policy and planning. In N. H. Hornberger \& S. L. McKay (Eds.), Sociolinguistics and language education (pp. 143-176). Bristol, UK: New Perspectives on Language and Education.

Sadoğlu, H. (2003). Türkiye'de ulusçuluk ve dil politikaları. İstanbul: İstanbul Üniversitesi Bilgi Üniversitesi Yayınları.

Schmidt, R. (1995, March). Language policy and racial domination: Exploring the linkages. Paper presented at the Annual Conference of the American Association for Applied Linguistics in Long Beach, California. 
Spicer, E. H. (1980). American indians, federal policy toward. In S. T. Thernstrom, A. Orlov \& O. Handlin (Eds.), Harvard Encyclopedia of American ethnic groups (pp. 114-122). Cambridge, MA: Belknap Press.

Şemseddin Sami (1317). Kamûs-ı Türkî. İstanbul: İkdâm Matbaası.

Tongul, N. (2004). Türk harf inkılâbı. Ankara Üniversitesi İnkılâp Tarihi Enstitüsü Atatürk Yolu Dergisi, s. $103-130$.

Ünaydın, R. E. (1954). Atatürk, tarih ve dil kurumları, hâtıralar. Ankara: Türk Tarih Kurumu Basımevi.

Wiley, T. G. (1996). Literacy and language diversity in the United States. Washington, DC: Center for Applied Linguistics and Delta Systems.

Wiley, T. G. (1999). Comparative historical analysis of U.S. language policy and language planning: Extending the foundation. In T. Huebner, K. A. Davis \& B. J. Lo (Eds.), Sociopolitical perspectives on language policy and planning in the USA (pp. 17-39). Amsterdam, NL: J. Benjamins.

Yavuz, K. (1999). Osmanlı Devleti'nin kuruluş devrinde Âşık Paşa'nın dil üzerine düşünceleri ve Garibnâme'sinde o devir Türkçesi ile ilgili bazı dikkatler. Uluslararası Eski Türkiye Türkçesi Toplantısı Bildiriler. Ankara: Türk Dil Kurumu Yayınları.

Yelten, M. (2007). Eski Anadolu Türkçesi sahasında yapılmış sure tefsirlerinin Türk dili açısından önemi. Uluslarası Eski Türkiye Türkçesi Toplantısı Bildiriler. Ankara: Türk Dil Kurumu Yayınları.

Yılmaz, M. Y. (2013). Türk dil planlaması bağlamında Türk Dil Kurumu (1932-1951). (Yayımlanmamış Doktora Tezi). İstanbul Üniversitesi Atatürk İlkeleri ve İnkılap Tarihi Enstitüsü, İstanbul.

Yılmaz, M. Y. (2014). İşgal dönemi Türkistan'da Rus dil planlaması ve Cedid Hareketi. Jasss Studies, 29, 339-349.

Korkmaz, Z. (2011). Eski Anadolu Türkçesinin Türk dili tarihindeki yeri ve yapısındaki temel nitelikler açısından genel bir değerlendirme. Türk Dili, 709, 39-47. 
